\title{
THE FERTILE DESERT: AGRICULTURE AND COPPER INDUSTRY IN EARLY ISLAMIC ARAVA (ARABAH)
}

\author{
HAGIT NOL
}

\begin{abstract}
The Arava is an arid region in the Southern Levant. Archaeological excavations and surveys in the area revealed dense settlement and sophisticated technologies from the eighth to ninth centuries - qanat water technology and copper production. Differences between the data of the middle and southern Arava suggest two separated economic systems. While the Southern Arava seems to be primarily an industrial area of copper that delivered the raw material to Ayla, the middle Arava was mainly agricultural and may be connected to trade routes. Studying the farming conditions of this arid area points to date palms as the main crop of the agricultural settlement. However, it is not yet clear where the Arava's produce was exported.
\end{abstract}

Keywords: Early Islam, Southern Levant, economy, agriculture, copper production, date palm

\section{INTRODUCTION}

The Arava ${ }^{1}$ is a geographical region in Southern Jordan/Israel. The arid area is known for its limited settlement in human history until Israeli settlement in modern times, although it flourished also in the Early Islamic period. Archaeological research in the Arava has revealed more than one hundred sites from the eighth to ninth centuries AD, including settlements, sites of copper production and qanats, a method for bringing groundwater to the surface.

This study has assembled most of the excavations and archaeological surveys that have been conducted in the region and examines the patterns of their findings. It shows two settlement patterns that are divided geographically-southern and middle Arava-and hence suggests two separated economic systems. The Southern Arava was primarily an industrial area of copper that performed the whole production process and delivered the raw material to Ayla. The middle Arava, in contrast, was mainly agricultural and produced copper to a lesser degree, with a so far unidentified source of raw material. The growing conditions of the arid Arava include brackish water, saline soil, high temperature, and dryness, which are suitable for raising date palms. Date palms were a known crop in that period and a highly profitable economic domain. On these grounds, date palms are probably the main crop in the agricultural settlement of the Arava.

The geographical definition of the Arava region is the Wadi Arabah (the Arabah rift valley), from the Dead Sea to the Gulf of Aqaba (Fig. I). The rift is bordered by the Negev Highlands to the West and the Edom and Moab Plateaus to the East, and is considered part of the Israeli Negev or the Jordan Rift Valley. The area is characterised by a hot and extreme climate, limited water sources, and shortage of arable land which may explain the relative lack of settlement throughout human history. The area, however, has two sources of copper, Timna and Feinan, and additional natural resources that do justify human settlement (Bienkowski 2006).

The climate of the region is hot and dry, particularly in the Southern Arava. The annual rainfall average is $50 \mathrm{~mm}$ in Southern Ghor, $70 \mathrm{~mm}$ in Ein-Hazeva, and $25 \mathrm{~mm}$ in Eilat, but it varies year by year (Ron I967, IIO-I5). Over July and August the heat averages $38-39^{\circ} \mathrm{C}$;

Address correspondence to: Hagit Nol,nolgit@yahoo.com 


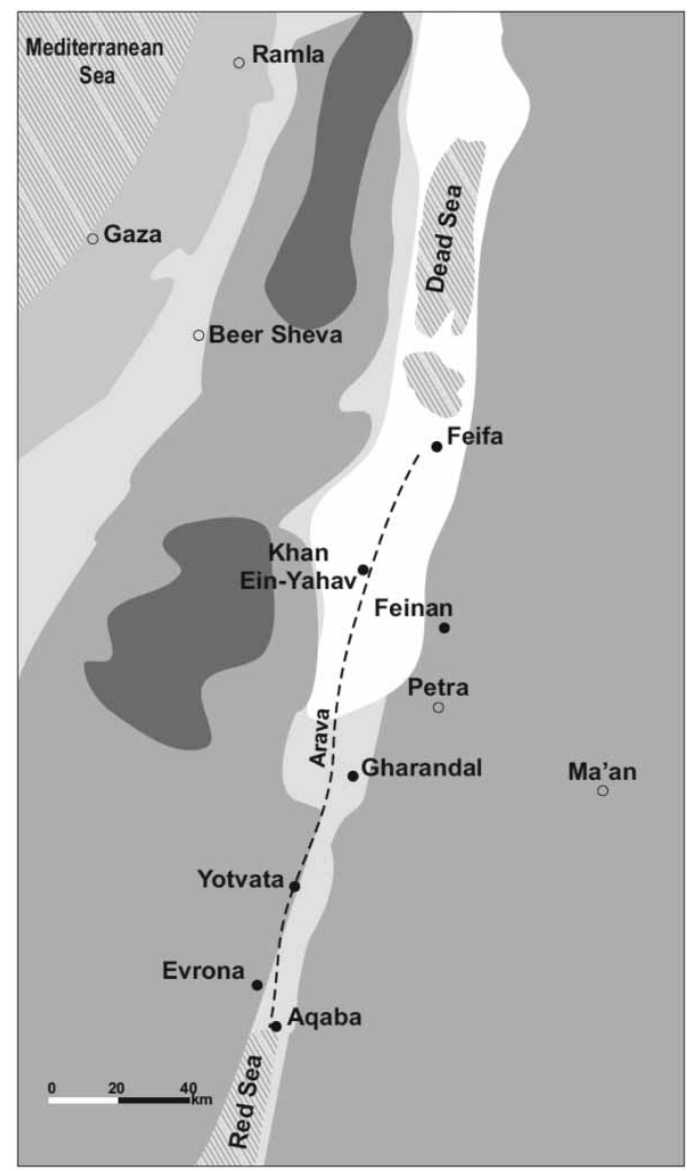

Fig. I. Wadi Arabah.

maximum temperatures can rise to $45^{\circ} \mathrm{C}$ in Eilat. During most winters the temperature is c. $20^{\circ}$ $\mathrm{C}$ above ground (Amiran, Shachar and Charney 1995), and the most difficult climatic phenomenon is frost (Harel and Nir 1975, I06), which damage many of the crops. Finally, the Arava is characterised by dryness, but according to Bruins (2006), humidity varied over different periods. For example, in the years $\mathrm{AD} 400-900$ the area was drier than usual, and became more humid in the years $\mathrm{AD}$ 900-I300.

The natural water sources of the Arava are springs, natural water holes (gevim) and thamilas, water in a wadi bed exposed naturally or by a shallow dig (Ron i967, 63-64). Yet in the Eastern Arava, most of the water is supplied by the wadis. Due to the higher amount of rainfall in the eastern Arava, the quality of the water in its springs is better than that of the west. In the southern Arava there are hardly any natural sources of water, except for some little supply in Wadi Yutum near Aqaba (Bruins 2006). One of the main problems is the brackish groundwater, as usual in arid lands (Ron 1967,43 ).

The soil of the Arava is mostly Hamada that is common in extreme desert climates and unsuitable for agriculture. The southern Arava, in contrast, contains alluvial fans resulting from wadi floods which enable agriculture and finding ground water. Few areas of the 
Arava, such as Yotvata and Evrona, are drainage basins with moist ground. In these regions, natural vegetation grows and can be used for pasture. Moreover, leaching the soils facilitates agriculture. Trees widespread in the oases of the Arava are Ziziphus spina-christi (Jujube) and Moringa Peregrina (Harel and Nir 1975, 44-45, I38, I46-I50).

Modern Israeli settlement in the Arava demonstrates that settlement is possible under certain conditions. The first condition would be encouragement by the government and the second, the use of sophisticated technology in profitable agricultural fields (Amiran, Shachar and Charney I995). Surprisingly, the eighth-ninth centuries AD also knew a large settlement enterprise. The early Islamic settlement in the Arava included the copper industry, as it had in both earlier and later periods. However, the extensive agricultural settlement is a distinguishing feature of the early Islamic period.

There are almost no literary sources of the eighth century in the Islamic world. For the study of the period, historians use mostly historical and geographical texts of the ninth and tenth centuries, combined sometimes with external sources and archaeological studies (Donner I998, I-3I; Hoyland 2006). These later texts mention settlements in some parts of Bilad al-Shàm (Greater Syria) but do not give any details on the rural or smaller settlements, and do not deal at all with the subject of agricultural settlement or metallurgic enterprises in the region.

Therefore, references to settlements in the Arava are scarce. Ayla is an exception in that it is mentioned in a few sources as a transit town between Mecca and Egypt (e.g., al-Balādhurī I936, 65, I74). The legend of the peace treaty between Ayla's bishop and the prophet is also described by a few authors (al-Balādhữ̄ ı866, 59; Yāqūt ı9o6, 39I; among others). Yet even Ayla has not been discussed in detail by the geographers-they do not mention its landscape, its facilities, or the residents' income sources. The limited number of textual sources might be the reason for the dearth of secondary historical research on the settlement of the Arava.

In contrast, several archaeological investigations have been conducted in the region, starting with the survey of Alois Musil in the late nineteenth century (King et al. I989; Avner 2008). These studies include Benno Rothenberg's research of the copper industry around Timna (Rothenberg I996-I997), Yosef Porath's investigation of the qanat systems (I987), Donald Whitcomb's excavations in Aqaba/Ayla (1987, I994, 2001) and several surveys on both sides of the valley (King et al. I989; MacDonald I992, I I9-25; Nahlieli 1992, I999; Whitcomb 1992; Smith and Niemi 1994; Avner and Magness 1998; Smith 2005).

This study is the first to assemble the existing studies, including unpublished surveys from Israel. It takes into account all human activity markers studied so far, whatever their character - a total of i 6 . Although the 'Arava' usually refers to the Rift Valley, 24 related sites on the adjacent mountains were also considered, including sites in the western part of the Southern Arava (Eilat Mountains) such as Horvat Bodeda, a few sites in the western middle Arava, and two sites in the East, including Feinan. It should be noted that information from the eastern Arava (between the Israeli/Jordanian border and the mountains) is scarce, which may have biased the conclusions. ${ }^{2}$ The material was examined in terms of patterns of settlement, culture, and economy. This article aims to identify the subsistence patterns of the Arava inhabitants and to understand their copper and agriculture economies.

\section{THE ARGHAEOLOGIGAL REGORD}

The material culture of the early Islamic Arava includes highly characteristic finds, with very little variety. The archaeological studies revealed unique architecture such as the courtyard house and the 'box-car' structure ${ }^{3}$; inscriptions and index fossils such as coins, stamps, steatite bowls, and pottery; finds relating to the copper industry, which include all elements of the 
production process - mining shafts or sites with ores, furnaces or slag; and finally, qanats. This article will present some relevant portable artefacts in dating context, but will focus on the two main technologies-copper and qanats. The subject of the architecture will be discussed elsewhere.

Cross-referencing the archaeological data of the Arava reveals two main clusters separated geographically-one cluster in the middle Arava and another in the Southern Arava (Fig. 2). Data from the northern Arava are extremely limited and had to be excluded from this study. The clusters differ in the quantity and quality of portable artefacts, in the relative frequency of finds related to qanats and to the copper industry and in the character of copper finds. An analysis of the patterns demonstrates at least two economic systems, based in different degrees on agriculture, copper production and trade, as will be discussed in the next paragraphs.

The middle site cluster contains 55 sites, including the excavated sites of Khan Ein-Yahav, Nahal Shahaq, and Nahal Omer. Geographically it was densely settled. The area has many water sources, both natural and artificial (qanat). Characteristic of the region is an abundance of artefacts, including more rare finds such as coins, jewelry, and inscriptions. The region also has finds relating to the copper industry, mostly slag, but no sites with active mining shafts. The

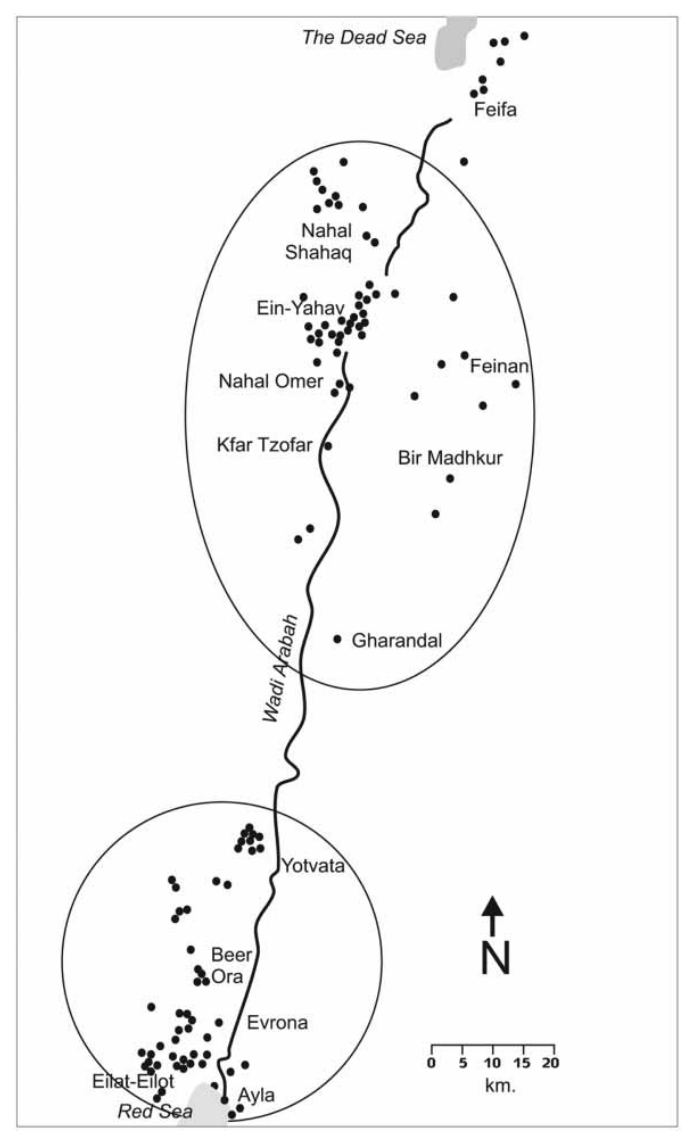

Fig. 2. The main site clusters of the Arava. 
southern site cluster contains 53 sites, including excavated sites such as Aqaba, Eilat-Eilot, Yotvata, Evrona, Beer-Ora, and the Nahal Amram mines. Unlike the middle site cluster, portable artefacts are mentioned in only half of the sites, mainly pottery. There is an abundance of copper finds, including mining sites and smelting sites. On the other hand, there is a distinct lack of water sources, with qanats in only Yotvata and Evrona and an irrigation system in Aqaba castle.

\section{DATING THE ARAVA SITES}

Up until the I99os, archaeological studies identified many of the Early Islamic sites as Byzantine or Roman. The shift in dating began with the works of Donald Whitcomb (I988) and Alan Walmsley (I992) in key Jordanian sites such as Khirbet Mafjar and Pella (Fihl). Since then, most studies in modern Jordan and Israel have used the 'new dating'. The metallurgical activities in the Arava, for example, were dated initially to the Roman period (Rothenberg I967a, I28-29) and later shifted to Early Islamic (Rothenberg I988, I996-I997). Likewise, the qanat activity in the western Arava was attributed to the Romans (Evenari, Shanan, and Tadmor I971, I78, still argued by Lightfoot 1997) and later changed by Porath to Early Islamic (I987).

The research sites were originally dated from Byzantine to Late Islamic. 6o out of the ir6 sites were attributed to Early Islamic period, five to the Late Islamic period, and 33 to the Byzantine period. In addition, I8 sites were published with no date, but with features that suggest an Early Islamic date (such as qanats). With regard to the Late Islamic sites (ninth-eleventh centuries), three of the five are related to the copper industry (Rothenberg I967b, 295296) and since they have never been re-investigated, their dating is not certain. Regarding the sites that are considered Byzantine, I accept the argument of Nahlieli (I992, 59) and Israel (personal communication) that most of them are actually Early Islamic. Notably, all published sites excavated in the Arava since the I99os have been dated to the Early Islamic period, even when identified as Byzantine in earlier surveys. An exception to this rule is sites of several phases, starting with Roman or Nabataean settlement, such as Roman Yotvata and Roman Aqaba.

The precise dating of the Arava sites is crucial for placing them in their historical context. Thus, after the initial classification of the sites as Early Islamic and not as Roman or Byzantine, the new dating also needs to be re-examined. As will be shown in Table I, some of the sites were dated from the seventh century to the eighth or early ninth centuries, although it now appears that most should be dated to the mid-eighth century and onwards. In contrast, other sites were dated from the eighth to the tenth centuries, even though radiocarbon assays (that were used in the same studies) indicated earlier origins. The table presents several primary Arava sites, their diagnostic artefacts, the original attributions, and more precise re-evaluations.

The main diagnostic finds of the Arava include pottery, stone vessels, and coins. Very little pottery has been found or published, but all types can be dated between the mid-eighth to early ninth centuries. For instance, Mahesh ware is dated to AD 750-800 and Coptic Glazed Ware is dated to the early eighth century (Whitcomb ig87, I989a, I989b). Mafjar Ware is dated to "the Abbasid period' (Whitcomb I988), AD 750-900, as are Ramle Mold ceramics (end of Umayyad/ Abbasid, according to Avissar I996, I58-59). Although stone vessels are usually difficult to date, steatite bowls can easily be identified, and are dated to the eighth to ninth centuries (Magness I994, 2004), or to the 'Abbasid period' as in Ayla (Whitcomb I987). Coins are considered here only as providing a terminus post quem of the site or occupation layer.

The table presents possible chronologies of selected sites and reflects the problems of the dating in research. Certainly most of the Arava was settled between the middle and the end of the eighth century, yet the exact period when all sites were active is still uncertain. Therefore, I conclude the dating of the settlement in the Arava to be the eighth and early ninth centuries. The city of Ayla is a clear exception, being occupied for a much longer period. It had been 
TABLE I: Re-dating selected sites of the Arava

\begin{tabular}{|c|c|c|c|c|c|c|}
\hline Site name & $\begin{array}{l}\text { Scholarly } \\
\text { attribution }\end{array}$ & Dating finds & $\begin{array}{l}\text { Terminus } \\
\text { post quem }\end{array}$ & Carbon I4 & $\begin{array}{c}\text { Mobile } \\
\text { artefacts }\end{array}$ & $\begin{array}{c}\text { Dates of } \\
\text { mobile } \\
\text { artefacts }\end{array}$ \\
\hline
\end{tabular}

\begin{tabular}{ll}
\hline Nahal Shahaq & Umayyad-Abbasid \\
(Israel, \\
Nahlieli, and \\
Ben Michael \\
I995) \\
$\begin{array}{ll}\text { Khan } & \\
\text { Ein-Yahav } & \\
\text { (Porath I987) } & \text { centuries }\end{array}$ \\
\end{tabular}

Kfar Tzofar $\quad 7$ th-9th centuries (Nahlieli I999, 255)

Al-Amar

(Nahlieli i999,

259)

Wadi el

Buweirida

(Nahlieli I999,

255)

Yotvata Late 7 th-late 8th

(Porath I987)

centuries

Evrona (Porath Late 7 th-late 8th I987) centuries

Eilat-Eilot 8th-9th centuries (Avner I998)

Wadi Tawahin 8th-Ioth centuries (Avner and Magness I998)
Coin (AD 734-
735) and lead
stamp of late
Umayyad/
Early
Abbasid

AD 734

Sandal lamp, Mid 8th mold lamp, century

Mahesh bowl,

Steatite

Decorated Mid 8th

Coptic bowl, century

Ramle mold ceramics, steatite

Fils of the AD 769 years AD 769-

774

Umayyad AD 696 coin with no dating $(\mathrm{AD}$ $696-750)^{11}$

Coin $(802 / 3) \quad$ AD 802

Several coins, AD 780 the latest from $\mathrm{AD} 780$

One date Mahesh ware, Late 8th of the 7 th century

steatite, ostracon century

dated to late 8th-early $9^{\text {th }}$ centuries

Several Mahesh ware, Early gth dates steatite, century between glazed mold AD 597 and bowl 768

One date Pottery 8th-Ioth of the Ioth 'dated to 8th- centuries? century Ioth centuries' 
Table i: Continued

\begin{tabular}{|c|c|c|c|c|c|c|}
\hline Site name & $\begin{array}{c}\text { Scholarly } \\
\text { attribution }\end{array}$ & Dating finds & $\begin{array}{l}\text { Terminus } \\
\text { post quem }\end{array}$ & Carbon I4 & $\begin{array}{l}\text { Mobile } \\
\text { artefacts }\end{array}$ & $\begin{array}{c}\text { Dates of } \\
\text { mobile } \\
\text { artefacts }\end{array}$ \\
\hline $\begin{array}{l}\text { Beer Ora (Site } \\
\text { 28) (Avner and } \\
\text { Magness I998) }\end{array}$ & 8th-9th centuries & & & $\begin{array}{l}\text { Several } \\
\text { dates } \\
\text { between } \\
\text { 7th to Ioth } \\
\text { centuries }\end{array}$ & $\begin{array}{l}\text { Pottery } \\
\text { 'dated to 8th- } \\
9^{\text {th centuries' }}\end{array}$ & $\begin{array}{l}\text { 8th-9th } \\
\text { centuries? }\end{array}$ \\
\hline $\begin{array}{l}\text { Beer Ora } \\
\text { 'village' (Israel } \\
\text { 2002) }\end{array}$ & $\begin{array}{l}\text { Umayyad to Early } \\
\text { Abbasid period }\end{array}$ & & & & $\begin{array}{l}\text { Steatite, } \\
\text { 'Early Islamic } \\
\text { pottery' }\end{array}$ & $\begin{array}{l}\text { 8th-9th } \\
\text { centuries }\end{array}$ \\
\hline
\end{tabular}

established already in the mid-seventh century, according to its excavator (Whitcomb I987) even though there is no archaeological evidence earlier than the eighth century (Walmsley 2000) - and was occupied till the eleventh or twelfth century. In addition, I suggest that the site of Wadi Tawahin (dated originally to the 8th - Ioth centuries) should be dated at least to the tenth century, having only a tenth-century date of Carbon I4 as published evidence.

\section{GOPPER PRODUGTION}

The copper industry has attracted human presence in the Arava throughout history. In general, copper production includes several stages: mining copper ores and flux, mechanic crushing of the ores, preparing the smelting load, and smelting and casting. The finds relating to copper industry in the Early Islamic Arava include a number of mining sites in the Timna area, most of them in Wadi Amram and Wadi Timna, several smelting sites in the southern and middle Arava, and some records of small scale copper smelting which Rothenberg defined as 'domestic industry' (1996-1997). Surprisingly, Feinan's area, the main center of the Arava copper industry in pre-modern history (Bruins 2006; Hauptmann 2006), operated only until the Roman period, or somewhat later, and resumed operation only in the thirteenth century (Hauptmann and Weisgerber I987; Jones, Levy, and Najjar 2012). Archaeological research shows that mineral production was common in Early Islam also in the neighboring areas in Saudi Arabia, such as Bureida, Njd, and Hijaz, including copper, gold, and steatite (de Jesus et al. i982; Kisnawi, de Jesus, and Rihani i983; Hester et al. I984).

The copper industry is found in both the middle and southern Arava, albeit to different degrees and with differences in the types of copper finds. The production was organised in mining sites, sites with ores, sites with furnaces, and sites with slag. As indicated in Table 2, the middle Arava is mostly a smelting area while the southern Arava is distinctively an 'industrial area' that includes all production procedures. This raises the question of the source of raw material in the middle Arava. It is possible that the slag result from secondary smelting of earlier slag, as already postulated in this area (Yekutieli, Shalev, and Shilstein 2005) and is possible owing to the specialised technology of the time (Rothenberg: personal communication).

The destination of the copper from the middle Arava remains uncertain and depends somewhat on finding the local source of the raw material. If, indeed, the main smelting industry was only re-smelting of earlier slag, then the quantity of the product would probably be limited and for domestic use only. That explanation does not clarify the existence of three smelting sites in the region. Alternatively, if there existed a hitherto unknown mining 
PALESTINE EXPLORATION QUARTERLY， I 47，I，2OI 5

TABLE 2: Copper data from Arava sites

\begin{tabular}{|c|c|c|c|c|c|c|c|c|}
\hline $\begin{array}{l}\text { Site } \\
\text { cluster }\end{array}$ & $\begin{array}{c}\text { Site } \\
\text { number }^{12}\end{array}$ & Site name & $\begin{array}{c}\text { Scholarly } \\
\text { interpretation }\end{array}$ & Slag & Ore & Furnaces & $\begin{array}{c}\text { Mining } \\
\text { shafts }\end{array}$ & Other \\
\hline \multirow[t]{10}{*}{ Middle } & I9 & & A smelting site & V & & & & \multirow{10}{*}{ Ash } \\
\hline & 25 & Site 58 & & $\mathrm{~V}$ & & & & \\
\hline & 28 & Khan & & $\mathrm{V}$ & & & & \\
\hline & & Ein-Yahav & & & & & & \\
\hline & 29 & Feidan & $\begin{array}{l}\text { Copper smelting } \\
\text { center }\end{array}$ & V & & & & \\
\hline & 30 & Site 59 & & V & & & & \\
\hline & 34 & & & $\mathrm{~V}$ & & & & \\
\hline & 47 & & & V & & & & \\
\hline & $4^{8}$ & $\begin{array}{l}\text { Khirbet } \\
\text { en-Nuhas }\end{array}$ & $\begin{array}{l}\text { Copper smelting } \\
\text { center }\end{array}$ & V & & & & \\
\hline & 54 & Feinan & & & & & V & \\
\hline \multirow[t]{19}{*}{ South } & 65 & Site $2 \mathrm{I} 3$ & & $\mathrm{~V}$ & & $\mathrm{~V}$ & & \\
\hline & $7 \mathrm{I}$ & Site IIE & & V & & & & \\
\hline & 77 & Site I4 & Smelting site & ? & & ? & & \\
\hline & 78 & Timna 24A & Mining cave & & & & V & \\
\hline & 80 & Site 37 & Copper mine & & V & & ? & \\
\hline & 82 & Site 64 & Smelting camp & $\mathrm{V}$ & & $\mathrm{V}$ & & \\
\hline & 83 & $\begin{array}{l}\text { Beer Ora, } \\
\text { village }\end{array}$ & Village & $\mathrm{V}$ & $\mathrm{V}$ & & & Crucible \\
\hline & 84 & $\begin{array}{l}\text { Beer Ora (site } \\
28)\end{array}$ & Smelting site & V & & $\mathrm{V}$ & & \\
\hline & 86 & $\begin{array}{l}\text { Nahal Amram } \\
\text { (site 38) }\end{array}$ & Mine & & & & V & \multirow[t]{11}{*}{$\begin{array}{l}\text { Mining } \\
\text { waste }\end{array}$} \\
\hline & 88 & Site 72 & Mine & & $\mathrm{V}$ & & $\mathrm{V}$ & \\
\hline & 89 & Evrona & Village & $\mathrm{V}$ & V & V & & \\
\hline & 90 & Site 184 & & & $\mathrm{~V}$ & & & \\
\hline & 93 & & & & & $?$ & & \\
\hline & $9^{6}$ & & & & & $\mathrm{~V}$ & & \\
\hline & 97 & Site 4 & & $\mathrm{~V}$ & & $\mathrm{~V}$ & & \\
\hline & IOI & Site 224 & & & & $\mathrm{~V}$ & & \\
\hline & I08 & Eilat-Eilot & Village & V & & & & \\
\hline & Iog & Eilat & & V & & & & \\
\hline & II3 & Site 217 & Mine & V & & & $\mathrm{V}$ & \\
\hline
\end{tabular}

site in the Feinan area, then one would expect larger quantities of raw material and then also copper export.

Unlike the middle Arava, the southern Arava is distinctively an 'industrial area' that includes all the production steps. Fig. 3 shows the way of the copper through the areafrom the mining sites, through sites with complete ore and sites with furnaces, to the farthest sites of slag. The figure shows distinctively that the industry remains were restricted to the west side of Wadi Arabah, outside the city of Ayla. Thus it appears that Ayla received the processed raw material, as proposed by Whitcomb (2006b). ${ }^{4}$

The main destination for the copper from Timna is not clear. Some scholars claim that it was used by Ayla's residents and visitors (Parker 2006; Whitcomb 2006b), but it seems more likely that most material was exported, maybe by means of the Häj markets, and/ 


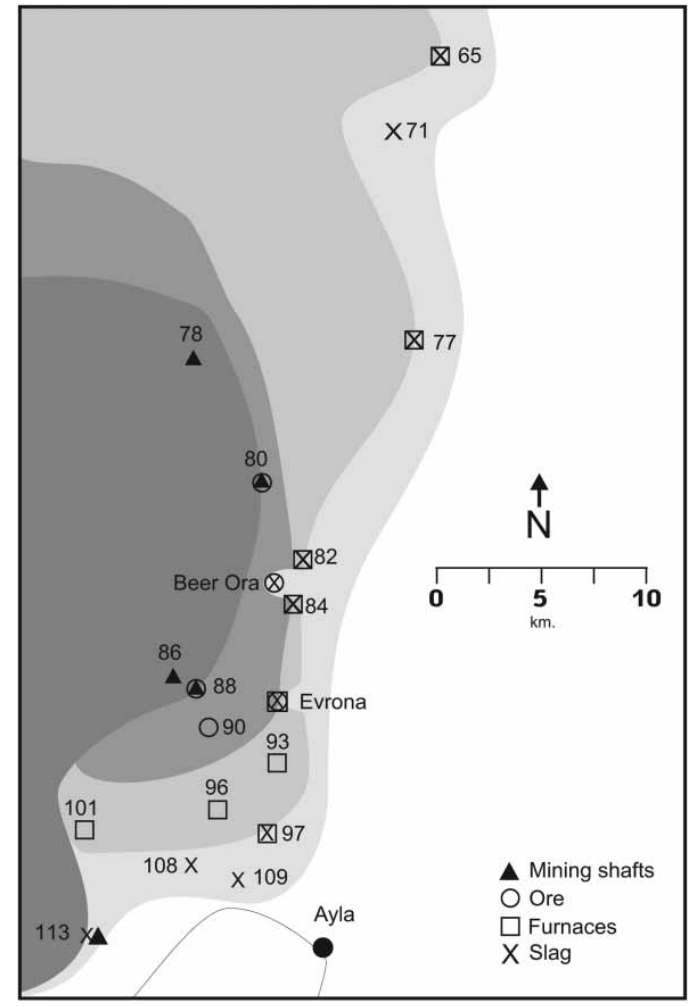

Fig. 3. The distribution of copper industry remains in the southern Arava.

or by sea. The copper and gold of the neighboring mines in Bureida, $\mathrm{Njd}$, and Hijaz of Saudi Arabia (de Jesus et al. 1982; Kisnawi, de Jesus, and Rihani I983; Hester et al. 1984) might have been used in the same manner. The trade option is supported by the commerce route which passed through Ayla (Whitcomb ig87; Sharon I993). Ayla was called a 'port' in some of Whitcomb's publications, and he suggested that 'Uthmān b. AAffān built one in $\mathrm{AD}$ 650 (Whitcomb I995, 25), but no archaeological evidence is mentioned for either port or maritime activity. Nevertheless, maritime studies suggest that trading with Ayla could have been by sea, even without a port (Anja Rutter, personal communication). Indeed, texts of the ninth and tenth centuries mention the Red Sea commerce, such as the gold from the Sudanese mines and the silver from Yemen, both exported to Mecca (Power 2009).

In the southern Arava, only in half of the sites mobile artefacts are mentioned. Some of the sites with no artefact presence mentioned are camp sites, qanat sites or sites that are related to Darb el-Hajj, but many of them are connected to the copper production. Interestingly, ten of the sites without artefacts have structures, when four out of them also revealed copper. The dating of a site with no artefacts presence is obscure. The reason might be a methodological flaw or that the find was deficient and therefore not mentioned. Despite that, the distinct number of sites with structures and few or no artefacts suggests a pattern.

The lack of mobile artefacts - together with the existence of structures in these sites and the industrial essence of the cluster-implies a seasonal activity. Apparently, such was the case 
in many mining areas in the Islamic realm (Shatzmiller I994, I75). The high temperatures in the summer do not allow work in the Eilat Mountains at all, indicating that the working seasons were presumably autumn and winter. Since most sites have no water source, it must be assumed that water was brought there by some organised method, either by private entrepreneurs or by some sort of authority. It can also be surmised that the work was done by corvée, as indicated in Anastasius' seventh-century description of Christians working near the Dead Sea (Hoyland 2006), or by slaves.

\section{QANATS AND AGRIGULTURE}

Despite of the Arava's climate and water quality, agriculture constitutes another major feature of the Early Islamic settlement. The archaeological evidence presents qanats, open canals and agricultural fields. The qanat method (Fig. 4) includes (I) The 'mother well' which is dug into the groundwater, (2) an underground tunnel that transfers water from the 'mother well' to an open canal in a slight slope, (3) a series of vertical maintenance shafts dug along the tunnel, and (4) an open canal which allows water to flow from the tunnel exit to the fields (Porath I987; Lightfoot 1997; Ahmadi, Samani, and Malekian 2010). It seems the technology originated under the Achaemenid rule, with the earliest archaeological evidence from Egypt, dating to 443 BC, but there might be earlier evidence from Arabia (Wilson 2008). In modern Iran, the longest qanat is $120 \mathrm{~km}$ long and the deepest active mother well measures $270 \mathrm{~m}$ (Ahmadi, Samani, and Malekian 20I0).

The water of the qanat is usually used for both irrigation and supplying drinking water (English 1968; Lightfoot 2000). Not much is written about the crops that are being farmed by this method. In Morocco, qanats irrigate palm groves (el Faiz and Ruf 20Io) and fields of seasonal vegetables. In Iran, it serves seasonal farming of wheat and barley in autumn, vegetables (tomatoes, eggplants, watermelon etc.) in spring/summer, and additional fruit trees such as figs, vines, and pomegranates (Cenesta 2003). The yield of qanats varies widely, according to groundwater characteristics, the soil quality, and the season, but a rough average of the Iranian qanats in the I950s was 30 gallons a minute (Cressey I958), equal to II3.6 1/minute.

The qanat system is a sustainable water source: in years with a high water table, water is flowing, and in other years, water might be insufficient. Differently, wells and drillings might be over-exploited until drying out the source (Cressey 1958; Ahmadi, Samani, and Malekian

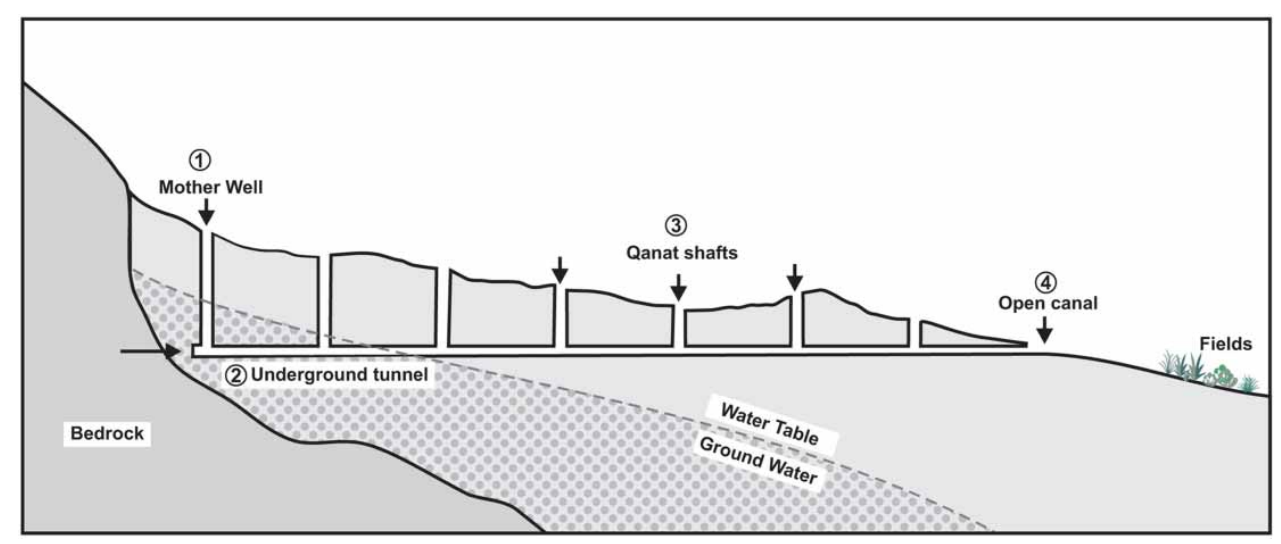

Fig. 4. The qanat system (after English i968, Fig. I). 
20I0). With or without sustainability awareness, a community that cooperates with its natural resources and adapts itself to the aquifer tempo can enjoy it for a long time. The challenge is finding the right crops that will not suffer in times of water scarcity. Alternatively, the qanat can be adapted to new needs, by digging it deeper, changing its directions, or moving the groves themselves, as is being practiced in Morocco (el Faiz and Ruf 2010). The high maintenance costs constitute another problem of the qanats, at least in modern Iran (Ahmadi, Samani, and Malekian 20I0), even though research conducted by the Iranian government showed a slightly higher profit to the farmer with qanats than with wells (Cenesta 2003).

Qanats are known in the Levant from the western Arava, the Jordan Valley, and southern Jordan (Fig. 5). In spite of former dates such as Roman or Persian (Evenari, Shanan, and Tadmor I97I, I78, forwarded by Lightfoot 1997) the technology has probably entered the area not before the Early Islamic period (Porath 1987). The three main areas with qanat systems in the Arava that have been published are Ein-Yahav, Evrona, and Yotvata. Aerial images of the region indicate qanats also on the eastern Arava (mentioned vaguely in Evenari, Shanan, and Tadmor I97I, I78), which would need further investigation. The six networks of Ein-Yahav were surveyed during the i950s, but only small segments have survived the modern agriculture. In Evrona, two parallel rows are known, a tributary and the exit of the tributary to an irrigation basin. It seems that the most sophisticated qanat system in the region was near Yotvata. This system contains six branched networks, one $5 \mathrm{~km}$ long, and the 'mother well' (Evenari, Shanan, and Tadmor I97I, I73-I77; Porath I987; Avner I99I).

One of the challenges of agriculture in arid zones is salt-saline soil caused by water evaporation and brackish groundwater. Briefly, the main effect of the salt is to prevent roots from absorbing essential nutrition, but some plants additionally suffer leaf burn (Bernstein I975). In contemporary Israel, the salinity of water is measured by its electrical conductivity degree (dS/ $\mathrm{m}$-deci-Siemens per metre) or by its chloride concentration level (ppm-parts per million). Water with 6oo ppm or less is considered sweet, over $4000 \mathrm{ppm}$ is considered salty (as seawater) and the middle values are for brackish water. In the middle Arava, the drilling water that is used for agriculture contains 1300 to $3000 \mathrm{ppm}$ and in the southern Arava 2300 to 4000 ppm. ${ }^{5}$ However, many crops tolerate salt to some degree and there are a few agricultural

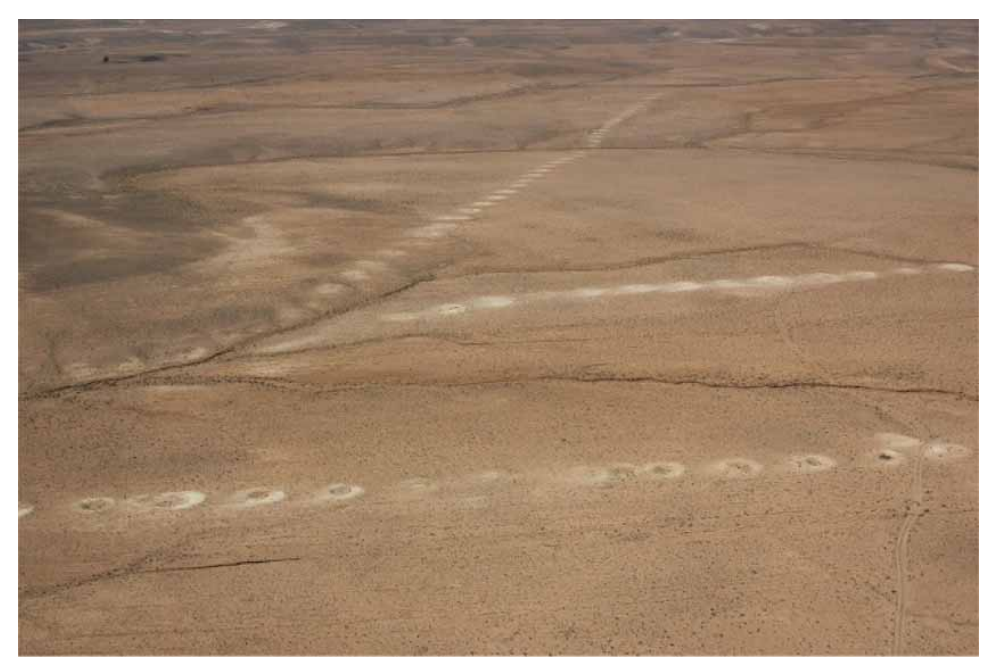

Fig. 5. qanat shafts near Ma'an. ${ }^{9}$ 
methods to manage salinity. The main method is leaching the soil while maintaining effective drainage. Some studies also suggest mulching the soil, or irrigating during nighttime, both methods aim at limiting evaporation (Bernstein 1975; Grattan 2002; Bezborodov et al. 2010).

There are several crops that are known in research as salt-tolerant plants in dry climates. The lists of Grattan (2002) and Maas (1993) assemble most of them, although different climates might change the results. The date palm is the only salt-tolerant fruit tree on their lists, yielding IOO percent harvest in I700 ppm and 75 percent in $5800 \mathrm{ppm}$. Recent agricultural research in Israel has also found several species of pomegranate that yield their maximum harvest even in $2700 \mathrm{ppm}$ (Eizenkot et al. 2009). The only salt-tolerant vegetable found on Grattan's list is asparagus, while red beet and zucchini squash are considered moderately tolerant. However, few vegetables such as cucumber, tomato, and spinach yield 75 percent with i850 ppm or more. Similarly, fruit trees such as almond, plum, peach, and citrus give 75 percent yield with I300-I500 ppm, and vine can even tolerate I700 ppm. Fig and olive are mentioned as moderately tolerant trees, but without precise values (Grattan 2002). Additional salt-tolerant crops are cotton, wheat, barley, and rye (Maas i993).

Plant remains from the Arava sites indicate the residents' diet and can give some indication as to the crops that were farmed in the region. On the sites of Nahal Shahaq, Nahal Omer, Khan Ein-Yahav, Eilat-Eilot and Evrona, date stones were found in a significant amount. Additional plant remains found included peach, barley, buckwheat, and Moringa Peregrina in Nahal Shahaq, almond in Eilat-Eilot, and olive, jujube, almond, peach, carob, wheat, and barley in Evrona. Other products made of date palm branches included mats and ropes (Porath I985, I3I, I44; Kislev I995; Avner I998; Nahlieli I999, 258).

Further aspects also indicate that date palm trees may have been an important crop of the Early Islamic Arava. Scholars have suggested the idea earlier, at least regarding the areas of Evrona or Yotvata (Evenari, Shanan, and Tadmor I97I, I75; Porath I985, I44), but it warrants more detailed examination. Besides tolerating brackish irrigation water, this crop requires a hot and dry climate. In fact, the hotter the climate, the better the yield, and if temperatures fall below $18^{\circ} \mathrm{C}$ it will not give any fruit at all. Another character of the date palms is their resistance to frosts (Cohen 2012), one of the Arava's climate phenomenons. Lastly, date palms can adapt to smaller amounts of water. Recent agricultural research in the Arava suggests that the yield does not change even in reducing 25 percent of irrigation portions (Kremer 20I4). That means that the yield will not suffer in years with a lower water table.

The literary sources might support the assumption of growing date palms in the Arava during Early Islamic period. The geographers of the tenth century, al-Maqdis̄i and al-Istakhrī, present several towns in Bilad al-Shäm that grew date palm trees, including Ramla, Tiberius, Baysan, and Jericho, as well as Zoar and Ayla in the Arava (Amar 2000, I76-88). There are very few known texts on the subject that date back before the tenth century, but trade in dates is mentioned in three of the Nessana papyri, dated from the late sixth century to middle seventh century (Kraemer I958, 26I-89) or somewhat earlier (Hoyland 2006). Growing palm trees in Palestine was also a common theme in Jewish texts of the Roman and Byzantine periods (London 20I0). Thus, we can assume that date palm arboriculture was known in the eighth century, but it remains uncertain in which areas of Bilad al-Shäm it was practiced.

The economic motive should also be considered when proposing farming date palms or other crops in the Arava. One of the main relative advantages of dates is their simple processing. The fruit dries naturally and can be stored and used for long periods, while olives, in comparison, need to be pickled for consumption and for storage, or crushed, pressed, and separated for oil (Curtis 2008). An additional advantage of the date palms is the abundance of products that can be made from them. All parts of palm trees can be used in some way (Fig. 6): trunk, fruit stalks and spikelets, leaves (including midribs, leaflets, spines, and leaf 

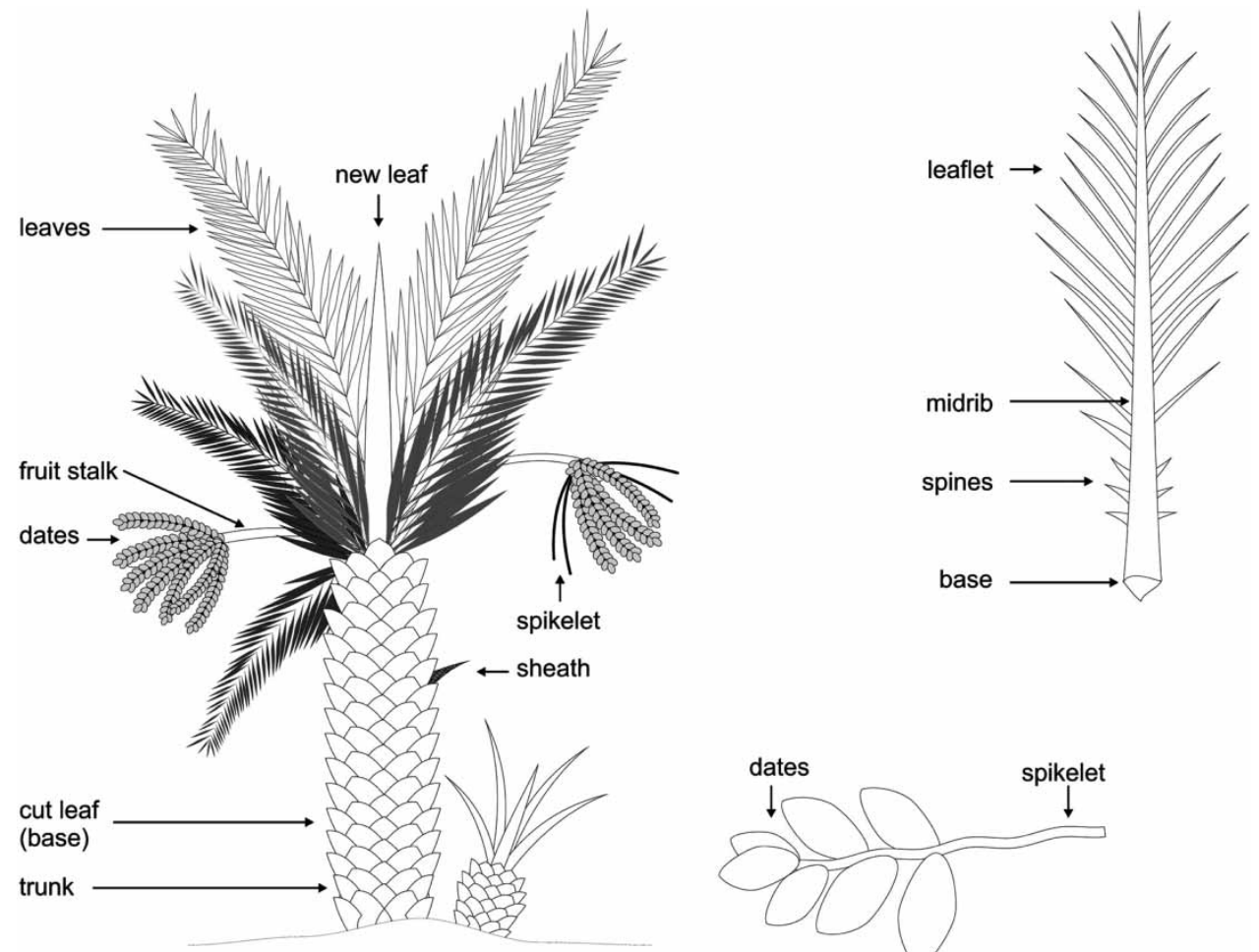

Fig. 6. Date palm components.

base), a fibrous sheath for the new leaves and sap of the trunk's vascular. The main uses are ropes, mats, baskets, and crates for domestic and agricultural use; building materials and furniture; secondary food products (juice, syrup, alcohol, sugar), and fuel (Barreveld I993). An example of the use of date palms for building purposes can be found in the Tinghir region in Morocco. There, traditional roofing uses quarters of trunks (which easily reach Io $\mathrm{m}$ length) as construction beams, and mats made of leaflets as a filter layer under the mud cover $^{6}$. In short, the low cost of processing and efficient exploitation can make date palm arboriculture profitable. In the Edict on Maximum Prices of Diocletian in AD 30I, the price of date fruits was six times more than the one of figs (London 2010). This factor suggests their comparative importance even four or five hundred years later.

Watson claimed that part of the 'agricultural revolution' of the Early Islamic period was the raising of crops not raised earlier because of lack of knowledge or lack of appropriate irrigation technology (Watson 1983, 78-96, I03-II). Importing the qanat technology enabled the cultivation of palm trees with brackish water of the dry and hot Arava. Indeed, in three of the five sites with date remains there were also qanats, and another site (Nahal Shahaq) was adjacent to such a system. Qanat maintenance is considered expensive, unless employing slaves or corvée, but setting up the system is much cheaper than digging wells (Ahmadi, Samani, and Malekian 20I0). Thus, the initial investment necessary for such an enterprise was low, and expenses for maintenance could likewise be kept at minimum, depending on the labor. 
To conclude, the harsh conditions of the Arava limit the arboriculture options. The crops need to be able to tolerate the saline soil and brackish water and to endure (or benefit from) the hot and dry climate. The low processing costs and high efficiency together with the high market value in Roman time make date palms a highly plausible choice as a fruit crop for the region. The results of the archaeo-botanic studies confirm this assumption, with a distinct evidence of date stones.

At the same time, some additional crops could have been farmed in the Arava. The botanical finds included olives from Evrona which might have been grown on the site or its surroundings. First, scholars agree that olives were manufactured or traded in Late Antiquity and other periods primarily as oil (Fall, Falconer, and Lines 2002; Curtis 2008; Kaniewski et al. 2012), which means that olive pips should be found where the tree was farmed (or where its fruits were pressed). Secondly, olives tolerate salt of $2700 \mathrm{ppm}$, when leached, and can endure a hot and dry climate (Arnon Dag, personal communication). Similarly, the barley that was found on two sites can probably grow in the Arava conditions. Regarding the finds of almond and peach, both are deciduous fruit trees that also require cold weather and therefore had to be imported. The same is true for wheat and buckwheat. Last, finds of Moringa and jujube suggest gathering of wild plants.

\section{TRADE ROUTES}

The trade destination for the produce of the Arava stays uncertain. The copper finds analysis has shown a clear path of raw material from the western sites of the southern Arava to Ayla. It can be only assumed that the agricultural yield of the southern Arava went through the same route. However, the following procedure or destination remains uncertain. For instance, did Ayla's artisans process the copper, maybe by minting, ${ }^{7}$ or was it exported as raw material?

The picture is even vaguer concerning the middle Arava. The first open question is the extent of the copper industry. Since no mine that operated in that period was found, the range of smelting activity is expected to be very limited, which seems to contradict the evidence of three smelting sites in the sub-region. We can assume that a limited source of copper would only be used in domestic needs or short distance trade, while a more significant source would be exported farther.

The second question relates to the trade routes and the destination of produce from the middle Arava. The map in Fig. 7 suggests routes from the middle cluster, west, to the Byzantine 'Negev Towns' (Nessana, Sobata, Eboda, Mampsis, Rehovot, Elusa, and Beer-Sheva). These routes have never been investigated archaeologically and therefore are only tentative, but they do resemble trade routes such as Ma'ale Akrabim, Darb es Sultan and the Spice Route-all known from other periods. Recent studies suggest that the 'Negev Towns', excluding Mampsis and Elusa, were active until at least the early ninth century, in spite of former perception (Urman I995; Magness 2003, I84-94; Gilead and Fabian 2008; Avni 2009). That means that the connection to the Arava is plausible.

When considering trade routes, attention should be drawn also to several contemporary sites in southern Jordan: Petra, Udhruh, Ma'an, and Humayma. The archaeological data from Petra and Udhruh, both Nabataean-Byzantine occupations, are limited. The excavations of Petra slightly indicates that the 'classical city' underwent changes during the sixth and seventh centuries, but continued to function along with its church to an undetermined degree and date (Fiema et al. 200I, 43 I-33). The excavation of Udhruh shows continuity of the site from the first century AD to the Ottoman period, in spite of stratigraphic problems. From the Early Islamic period, four Christian inscriptions in Arabic were discovered. One of the inscriptions mentions the year ' 705 ' which, according to its researchers, can mean the 


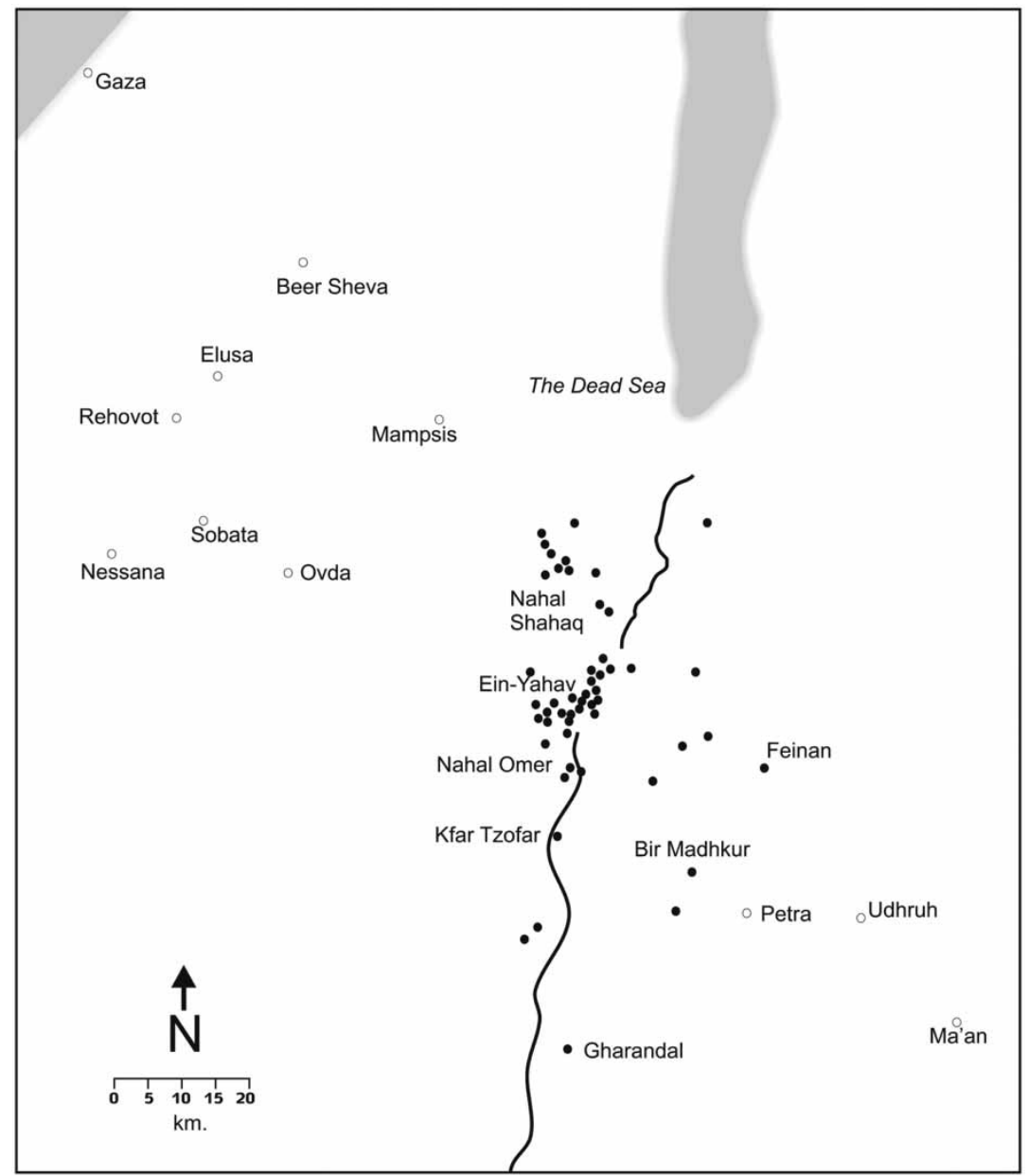

Fig. 7. The middle Arava and adjacent sites.

years $\mathrm{AD} 642$ to $8 \mathrm{II}$ (al-Salameen et al. 20II). In addition, qanat systems were found near the site, apparently for agriculture (Abudanh and Twaissi 20I0). In the area of Ma'an, three courtyard structures were surveyed, dated to Umayyad period and attributed to agricultural activities (Genequand 2003). Qanats were detected also in that area (Abudanh and Twaissi 20I0; Fig. 5).

The last related settlement in southern Jordan is Humayma. The site was excavated in several spots and yielded rich finds from the Nabataean to the Abbasid periods (Oleson et al. 1993). Among the structures are a courtyard house and an adjacent mosque. The scholars identified the complex as the Abbasid family residence, mentioned by al-Balādhuri and al-Tabari, and therefore dated it to the early eighth century (Foote i999; Schick 2007). It seems that were it not for the identification by the literary sources, the site could be dated to the late eighth or the ninth century, relying on the archaeological data. For example, panels of carved ivory which were found in the main structure preface the dates of known 
equivalents from the ninth century (Foote I999). Dating Humayma to the late eighth or early ninth century could fit perfectly with the few certain dates of the Arava.

To conclude, the four sites in southern Jordan were active during Early Islam, but their precise date is obscure. Thus, their connection to the Arava is not certain but entirely possible. The limited archaeological data of the eastern side of the Wadi makes it impossible to determine which connections existed between the Arava (and the Negev) to southern Jordan. Was the trade working into both directions (east-west), via the Arava including its produce, or was it directed west only, towards the sea? If the latter, was the starting point of the trade southern Jordan or the Arava? Either way, the final destination is not clear yet. Ramla would be one possibility, another Gaza or Ascalon, or even trade further afield on the maritime routes.

One step towards an answer is an examination of possible reasons for the arboriculture enterprises. Fall, Falconer, and Lines (2002) claim that since early history the harvest of orchards has been a direct result of urbanism and regional trade. Watson also argues that one of the incentives of agricultural development in the Islamic period was city needs (1983, I30-32). In other words, the city dwellers demanded food products that could be supplied only by extensive agriculture outside the city. Accepting that hypothesis means that the main yield of the Arava - the dates - was destined mostly for consumption in a city. In that case, the next investigation would have to inquire whether the markets of adjacent big settlements such as Ayla and Beer-Sheva were the target, or whether we are dealing with a long-distance trade to specific bigger settlements.

This view has become the accepted paradigm, but as persuasive as it may be, the meaning of specific cities and their economic behaviour can only be ascertained with recurrence to their historical and local contexts (Abu-Lughod I969; Abrams I978). Besides the many definitions of urban spaces, they are also being practiced differently, which determines their market needs. That can include, for example, variant use of space (is there agriculture within the dwelling areas?), or social structure (are there groups or individuals who do not produce their own food?). Therefore, orchard harvest is not necessarily connected to 'cities'. The remains of almonds and peach, imported from colder regions, into the (possibly non-urban) Arava sites support that notion. The incentive can still be demands by a non-self-productive group, such as soldiers, but not necessarily city dwellers.

The identity of the initiator might shed light on the motivation for establishing the agricultural enterprise in the Arava. I have suggested elsewhere (Nol 2014) that the archaeological data of the Arava implies involvement by some authority within the settlement. This authority could mean a centralised administration known from other regions (not before the the tenth century), or the Umayyad family members. If the Arava enterprises were managed by a centralised administration, then we can also expect an organised trade to specific destinations or certain social groups (for example, the army, or the capital city and the court). Conversely, if the Arava enterprises were private projects of the ruling family or local elites, then one should expect more spontaneous market motivations.

It is not clear what brought most of the Arava settlement to an end in the gth century. It has been suggested, for instance, that the cause was the rebel suppression by the army in $807 \mathrm{AD}$ (Porath i987). I would prefer the assumption that the same factor that drove the sudden Arava settlement-arboriculture of date-palms - is the one that also brought about its end. Only, the cease of rural settlement is not unique to the Arava but a widespread phenomenon which is also attested in the Negev, northern Jordan and elsewhere (Morony I984; Walmsley I992). It is likely that a shift to another economic system, maybe more centralised and industrialspecialised, ${ }^{8}$ led to the end of the enterprises, to migration and finally to the abandonment of the old rural settlements. The fact that Ayla continued to function for at least another 300 years supports the notion that it had alternative resources or was self-subsistent. 
The Arava is an arid area known for its limited settlement in human history. Surprisingly, the archaeological research in the region has revealed more than one hundred sites from the eighth to ninth centuries $\mathrm{AD}$, including settlements, sites of copper production and qanats. Examination of the findings and their patterns demonstrated different characteristics in the middle and the southern Arava. The absence of distinct connections between the two clusters, together with diverse patterns in the archaeological data, suggests two separated economic systems.

The southern Arava was mostly an industrial area for copper production, with a limited agricultural activity. It has performed the whole copper production process and delivered the raw material to Ayla. From Ayla, it may have been exported by land or by sea. It is possible that the agricultural yield of the southern Arava, from Evrona and Yotvata, went through the same route. The middle Arava, in contrast, was primarily agricultural, but also has evidence for copper smelting activity. Since no mining shafts operated in that period, it is plausible that the smelting activity consisted of re-smelting previous slag, possible due to the sophisticated technology of the time. The limited produce might have been exported in short-range trade. However, the agricultural yield from the middle Arava was probably traded for longdistance, to Beer Sheva, Ramla or Gaza, or even farther via maritime routes.

The growing conditions of the area-including brackish water, dryness, and high temperatures - enable the farming of very few crops. The most suitable crop for these conditions is date palm. Date palms were a known crop in that period and a highly profitable economic domain, and it was distinctively the main botanic find in the Arava sites. Hence, that was presubably the main crop farmed in the Arava in the Early Islamic period. It might have been even the raison $d$ etre of the settlement in the middle Arava. While the common paradigm argues that cities were the main incentive for establishing and harvesting orchards, I suggest the question should be examined contextually. At this stage, we cannot reject the notion of a more spontaneous economy and trade, destined for different consumers, sponsored by private initiators.

\section{ACKNOWLEDGEMENTS}

The data for this article are taken from my MA thesis submitted to Ben Gurion University. It was written under the supervision of Yuval Yekutieli and Nimrod Hurvitz, to whom I owe my gratitude. I am also grateful to Steven Rosen for his helpful readings and his never ending support and to Stefan Heidemann, Anja Rutter, David Kennedy, Travis Hearn, Arnon Dag, Yossi Yaniv, Nitzan Amitai-Preiss, Ian Jones, and Gideon Bloom for their generous assistance. Several additional thanks go to Ron Haran for the maps and illustrations, the editor and reviewers for their useful remarks, and The Israel Science Foundation (ISF), Grant No. I676/ı for research on 'The Formation of a Muslim Society in Palestine (ca. C.E. 600-1500)' for its support.

NOTES

\footnotetext{
1 The sites and regions names will usually be presented in their native language form (Arabic for Jordan and Hebrew for Israel), unless they have a known term in English. The term Wadi is used for describing a water stream also in Israel (Nahal in Hebrew), as the common term in English. The site Wadi Tawahin is an exceptional Arabic name for an Israeli site. For the region, of the two variants the Hebrew name Arava was chosen, not Arabah.

${ }^{2}$ King et al. (I989) mention that for security reasons, their team was not permitted to survey west of the Jordanian Arava road. It is possible that the APAAEM project does not supply any photos taken west of Feinan or Gharandal for similar reasons.
}

3 The box-car type is a tentative term denoting a long, rectangular structure with a number of rooms facing one entry direction. It resembles the 'modular units' of Magness (2004; Whitcomb 2006a), as brought to my attention by Itamar Taxel, but the latter has a more complicated architectural plan.

${ }^{4}$ Lately, Damgaard (2009) mentioned copper slag under Ayla's mosque that might come from the eighth century $\mathrm{AD}$. That data were left out of this study since the information was published only partly and the slag was in secondary use.

${ }^{5}$ Information regarding $\mathrm{dS} / \mathrm{m}$ maesures, in the middle Arava: http://www.arava.co.il/cgi-webaxy/item?3 and in the southern Arava: http://he.aravard.org.il/ 
soil-and-water-2/o6sawsalinere/, accessed 25 January 2014. Information on the ppm values were received from Gideon Bloom, a farmer from Hazeva, by personal communication.

${ }^{6}$ Information is based on personal knowledge of Mohamed ELHamdaoui, a former resident of the Tinghir region.

7 No minting remains have been found in Aqaba, but there are several coins apparently from Ayla's mint (Ramadan 2010a, 2010b). I thank Nitzan Amitai-Preiss for the initial reference.

${ }^{8}$ Since the roth century, industrial centres such as the paper industry of Tiberias have been mentioned in the literary sources. Industrial remains were detected also during archaeological investigations of that period, e.g. the sugar production in the southern Ghor.

9 APAAME_20070419_FFR-oi36, taken by Francesca Radcliffe.

${ }^{10}$ The site name distinguishes it from the adjacent site of Ein-Yahav and does not necessarily mean it had acted as a khan.

11 The 'Transition period' coins were struck from the beginning of the Umayyad rule in the 66os, but the first Arab epigraphic coins in Syria were minted presumably only from 696-699 AD (Heidemann 2010).

12 An index of the sites and their numbering can be found at $\mathrm{Nol} 2008$.

\section{BIBLIOGRAPHY}

Abrams, P., 1978. 'Towns and economic growth: some theories and problems', in P. Abrams, and E. A. Wrigley (eds.), Towns in Societies, Cambridge: Cambridge University Press, 9-33.

Abudanh, F., and Twaissi, S., 20Io. 'Innovation or technology immigration? The Qanat systems in the regions of Udhruh and Ma'an in southern Jordan', BASOR 560, 67-87.

Abu-Lughod, J., I969. 'Varieties of urban experience: contrast, coexistence and coalescence in Cairo', in I. Lapidus (ed.), Middle Eastern Cities, Berkeley and Los Angeles: University of California Press, I59-182.

Ahmadi, H., Samani, A. N., and Malekian, A., 2010. 'The Qanat: a living history in Iran', in G. Schneier-Madanes, and M.-F. Courel (eds.), Water and Sustainability in Arid Regions, Springer (e-book), I25-138, <http://link.springer. com/book/I0.1007\%2F978-90-48I-2776-4>

Amar, Z., 200o. Eretz Israel Crops in the Middle Ages, Jerusalem: Yad Izhak Ben-Zvi (Hebrew).

Amiran, D., Shachar, A., and Charney, I., I995. 'Eilat and the Arava settlements - a geographic study', in Y. Aviram et al. (eds.), Eilat and the Arava, Jerusalem: The Israel Exploration Society and the Israel Authority of Antiquities, 335-367 (Hebrew).

Avissar, M., I996. 'The Medieval Pottery', in A. Ben-Tor, M. Avissar, and Y. Portugali (eds.), Yoqne' am I: The Late Periods, Jerusalem: Institute of Archaeology.

Avner, R., I998. 'Eilat-Eilot: a village form the Early Islamic period', Atiqot 21, 36*-39* (Hebrew).

Avner, U., I991. 'Evrona Farm', Excavations and Surveys in Israel 96, 44 (Hebrew).

Avner, U., 2008. 'Eilat Region', NEAEHL, V, Supplementary Volume, Jerusalem: Israel Exploration Society and Biblical Archaeology Society, I704-I7II.

Avner, U., and Magness, J., I998. 'Early Islamic settlement in the southern Negev', BASOR 310, 39-55.

Avni, G., 2009. 'The Early Islamic conquest of Palestine-an archaeological view from the south, I' July lecture at 'Material Evidence and Narrative Sources', Interdisciplinary Studies of the History of Islamic Societies, the I4th Annual Workshop of the Department of Middle East Studies at Ben-Gurion University of the Negev.

al-Balādhữ̄̄, Ahmad b. Yahyā, ı866. Kitäb Futūh al-Buldān, M. J. Goeje (ed.), Leiden: Brill.

al-Balādhur̄̄, Aḥmad b. Yaḥyā, ı936. Ansāb al-Ashrāf, Vol. V, S. D. F. Goitein (ed.), Jerusalem: Hebrew University Press.

Barreveld, W. H., I993. Date Palm Products (FAO Agricultural Services Bulletin IOI), Rome: Food and Agriculture Organization of the United Nations; <http://www.fao.org/docrep/to68ie/to68ı eoo.HTM>.

Bernstein, L., I975. 'Effects of salinity and sodicity on plant growth', Annual Review of Phytopathology I3, 295-312.

Bezborodov, G. A. et al., 2010. 'Mulching and water quality effects on soil salinity and sodicity dynamics and cotton productivity in Central Asia', Agriculture, Ecosystems E Environment I38 (I-2), 95-IO2.

Bienkowski, P., 2006. 'The Wadi Arabah: meaning in a contested landscape', in P. Bienkowski, and K. Galor (eds.), Crossing the Rift: Resources, Routes, Settlement Patterns and Interaction in the Wadi Arabah, Oxford: Oxbow, 7-28.

Bruins, H. J., 2006. 'Desert environment and geoarchaeology of the Wadi Arabah', in P. Bienkowski, and K. Galor (eds.), Crossing the Rift: Resources, Routes, Settlement Patterns and Interaction in the Wadi Arabah, Oxford: Oxbow, 29-44.

Cenesta (Centre for Sustainable Development), Iran, I.R., 2003. Proposal for a candidate site of Globally Important Ingenious Agricultural System (GIAHS): Qanat Irrigation Systems: An ancient water distribution system allowing specialised and diverse cropping in desert regions of Iran, ${ }_{5}$ March 2003, ftp://ftp.fao.org/sd/SDA/GIAHS/final_qanats_proposal.pdf [accessed 26 December 20I3].

Cohen, Y., 2012. 'The global warming: heaven for the date-palms in Israel?', Alon Hanotea 66.4, 32-34 (Hebrew); <http://www.perot.org.il/Alon/201204/3.pdf>.

Cressey, G. B., I958. 'Qanats, Karez, and Foggaras', Geographical Review 48, 27-44.

Curtis, R. I., 2008. 'Food processing and preparation', in J. P. Oleson (ed.), The Oxford Handbook of Engineering and Technology in the Classical World, Oxford: Oxford University Press, 369-92.

Damgaard, K., 2009. 'A Palestinian Red Sea Port on the Egyptian Road to Arabia: Early Islamic Aqaba and its Many Hinterlands', in L. Blue et al. (eds.), Connected Hinterlands: Proceedings of Red Sea Project IV, (BAR International Series 2052), Oxford: Archaeopress, 85-98.

De Jesus, P. S. et al., I982. 'Preliminary report of the ancient mining survey i98I (I40I)', Atlal 6, 63-79.

Donner, F. M., I998. Narratives of Islamic Origins: The Beginning of Islamic Historical Writing, Princeton: Darwin Press. 
Eizenkot, A. et al., 2009. 'Reaction to water in pomegranate', Alon Hanotea 63.I, 26-28 (Hebrew), <http://www.perot. org.il/Alon/orog/bhinat_tguva.pdf>.

English, P. W., I968. 'The origin and spread of qanats in the old world', Proceedings of the American Philosophical Society II2, I70-I8I.

Evenari, M., Shanan, L., and Tadmor, N., I971. The Negev: The Challenge of a Desert, Cambridge: Harvard University Press.

el Faiz, M., and Ruf, T., 20I0. 'An introduction to the Khettara in Morocco: two contrasting cases', in G. SchneierMadanes, and M.-F. Courel (eds.), Water and Sustainability in Arid Regions, Springer I5I-I63. (e-book), <http://link. springer.com/book/I0.1007\% $\%$ F978-90-48I-2776-4>.

Fall, P. L., Falconer, S. E., and Lines, L., 2002. 'Agricultural intensification and the secondary products revolution along the Jordan Rift', Human Ecology 30, 445-482.

Fiema, Z. T. et al., 200I. The Petra Church, Amman: American Center of Oriental Research.

Foote, R. M., i999. 'Frescoes and carved ivory from the Abbasid family homestead at Humeima', $7 R A$ I2, 423-428.

Genequand, D., 2003. 'Ma'ān, an Early Islamic settlement in southern Jordan: Preliminary Report on a survey in 2002', ADAf 47, 25-35.

Gilead, I., and Fabian, P., 2008. '7ooo years of settlement: the archaeological remains from Beer-Sheva from the sixth millennium B.C. to the end of the first millennium AD', in Y. Gradus, and E. Meir-Glitzenstein (eds.), Beer-Sheva: Metropolis in the Making, Beer Sheva: Ben Gurion University, 303-33I (Hebrew).

Grattan, S. R., 2002. 'Irrigation water salinity and crop production', ANR Publication 8066, University of California; $<$ http://anrcatalog.ucdavis.edu> [accessed i5 November 2013].

Harel, M., and Nir, D., I975. Geography of Eretz-Israel, Tel Aviv: Am Oved (Hebrew).

Hauptmann, A., 2006. 'Mining archaeology and archaeometallurgy in the Wadi Arabah: the mining districts of Faynan and Timna', in P. Bienkowski, and K. Galor (eds.), Crossing the Rift: Resources, Routes, Settlement Patterns and Interaction in the Wadi Arabah, Chippenham: Oxbow, I25-I34.

Hauptmann, A., and Weisgerber, G., ig87. 'Archaeometallurgical and mining archaeological investigations in the area of Feinan, Wadi 'Arabah (Jordan)', $A D A 7$ 31, 419-437.

Heidemann, S., 2oro. 'Chapter i6. Numismatics', in C. Robinson (ed.), Cambridge New History of Islam. Vol. I: The Formation of the Islamic World, Sixth to Eleventh Centuries, Cambridge: Cambridge University Press, 648-779.

Hester, J. et al., I984. 'Preliminary Report on the third phase of ancient mining survey, southwestern province-I403 AH ig83', Atlal 8, I I5-I4I.

Hoyland, R., 2006. 'New documentary texts and the Early Islamic state', BSOAS 69, 4II-416.

Israel, Y., 2002. 'Beer Ora (South-East)', Excavations and Surveys in Israel I I4, I25-I29 (Hebrew).

Israel, Y., Nahlieli, D., and Ben Michael, J., I995. 'The Nahal Shahaq site: an Early Islamic settlement in the Northern 'Arava', Atiqot I4, I*-26* (Hebrew).

Jones, I. W. N., Levy, T. E., and Najjar, M., 20I2. 'Khirbat Nuqayb al-Asaymir and Middle Islamic Metallurgy in Faynan: surveys of Wadi al-Ghuwayb and Wadi al-Jariya in Faynan, Southern Jordan', BASOR 368, 67-IO2.

Kaniewski, D. et al., 2012. 'Primary domestication and early uses of the emblematic olive tree: alaeobotanical, historical and molecular evidence from the Middle East', Biological Reviewes 87, 885-899.

King, G. R. D. et al., I989. 'Survey of Byzantine and Islamic sites in Jordan: third preliminary report (I982), the Wadi 'Arabah (Part 2)', ADA7 33, I99-2I5.

Kislev, M. E., I995. 'Plant remains from the Nahal Shahaq site', Atiqot 26, I5*-18* (Hebrew; English abstract, p. I I4).

Kisnawi, A., de Jesus, P. S., and Rihani, B., I983. 'Preliminary report on the mining survey, Northwest Hijaz, I982', Atlal $7,76-83$.

Kraemer, C. J., Jr., I958. Excavations at Nessana. Vol. 3: Non-Literary Papyri, Princeton: Princeton University Press.

Kremer, S., 20I4. 'A long-term effect of water portions and irrigation frequency on the yield of Medjool dates-Final Report for the period 2003-20I3', Reports of Northern and Middle Arava $R$ E⿱ D (Hebrew). http://www.arava.co.il/ cgi-webaxy/sal/sal.pl?lang=he\&ID=457087_arava20 I2\&act=show\&dbid=files\&dataid= I2 I7 (accessed IO February 2014).

Lightfoot, D. R., I997. 'Research note: Qanats in the Levant: hydraulic technology at the periphery of early empires', Technology and Culture $38,432-45^{\mathrm{I}}$.

Lightfoot, D. R., 2000. 'The origin and diffusion of Qanats in Arabia: new evidence from the northern and southern Peninsula', Geographical fournal I66, 215-226.

London, A., 2010. 'The dates industry in Eretz Israel during the Roman and Byzantine periods', Alon Hanotea 64.6, 374I (Hebrew); <http://www.perot.org.il/Alon/o4io/6.pdf>.

Maas, E. V., I993. 'Testing crops for salinity tolerance', in J. W. Maranville et al. (eds.), Workshop on Adaptation of Plants to Soil Stresses, INTSORMIL publication 94-2, Lincoln: University of Nebraska, 234-247.

MacDonald, B., 1992. The Southern Ghors and Northeast 'Arabah Archaeological Survey, Sheffield: J. R. Collis.

Magness, J., I994. 'The dating of the black ceramic bowl with a depiction of the Torah shrine from Nabratein', Levant 26, $199-206$.

Magness, J., 2003. The Archaeology of the Early Islamic Settlement in Palestine, Winona Lake: Eisenbrauns.

Magness, J., 2004. 'Khirbet Abu Suwwana and Ein 'Aneva: two Early Islamic settlements on Palestine's desert periphery', in D. Whitcomb (ed.), Changing Social Identity with the Spread of Islam: Archaeological Perspectives, Chicago: University of Chicago, i I-23.

Morony, M. G., I984. 'Landholding and Social Change: Lower al-'Iraq in the Early Islamic Period', in T. Khalidi (ed.), Land Tenure and Social Transformation in the Middle East, Beirut: American University of Beirut, $209-222$.

Nahlieli, D., I992. The Neger Highland and the Arava in the Beginning of Islam Era (unpublished MA thesis), Tel Aviv University (Hebrew). 
Nahlieli, D., I999. The Negev between the 7 th and the IIth Centuries AD in light of Archaeological Findings and Historical Research (unpublished PhD Dissertation), The Hebrew University of Jerusalem (Hebrew).

Nol, H., 2008. Settlement, Economy and State in the Arava during the Early Islamic Period from the Archaeological Data (unpublished MA dissertation), Ben Gurion University of the Negev, Beer-Sheva (Hebrew).

Nol, H., 2014. 'Settlement and rule in the eighth-ninth centuries: the Arava as a case study', Cathedra I53, 7-34 (Hebrew).

Oleson, J. P. et al., I993. 'The Humeima Excavation Project: Preliminary Report of the I99I-I992 seasons', ADAf 37 , $46 \mathrm{I}-5 \mathrm{O} 2$.

Parker, T. S., 2006. 'Roman Aila and the Wadi Arabah: an economic relationship', in P. Bienkowski, and K. Galor (eds.), Crossing the Rift: Resources, Routes, Settlement Patterns and Interaction in the Wadi Arabah, Oxford: Oxbow Books, $223-230$.

Porath, Y., I985. Ancient Irrigated Agriculture and its Facilities in the Arid Zones of Eretz Israel (unpublished PhD dissertation), Tel Aviv University (Hebrew).

Porath, Y., I987. 'Qanats in the Arava', Qadmoniot 20 (79-80), Io6-II4 (Hebrew).

Power, T., 2009. 'The expansion of Muslim commerce in the Red Sea basin, c. AD 833-969', in L. Blue et al. (eds.), Connected Hinterlands: Proceedings of Red Sea Project IV; Held at the University of Southampton, BAR International Series 2052, Oxford: Archaeopress, III-II8.

Ramadan, T., 20ıа. 'The standing Caliph coins of Aylah-Filastin', Journal of the Oriental Numismatic Society $203,3-6$.

Ramadan, T., 20Iob. 'An Umayyad post-reform coin of Aylah: a concise analysis', fournal of the Oriental Numismatic Society 205, IO-I2.

Ron, Z., I967. Eilot Region Survey, Eilot: Hevel Eilot Regional Council Press (Hebrew).

Rothenberg, B., I967a. The Negev Secrets: Archaeology in the Negev and the Arava, Givatayim/Ramat-Gan: Masada (Hebrew).

Rothenberg, B., I967b. 'Archaeological sites in Southern Arava and in Eilot region', in Z. Ron, Eilot Region Survey, Eilot: Hevel Eilot Regional Council Press, 283-332 (Hebrew).

Rothenberg, B., I988. 'Early Islamic copper smelting - and worship - at Beer Ora, southern Arabah (Israel)', Institute of Archaeo-Metallurgical Studies i2, I-4.

Rothenberg, B., I996-I997. 'Researches in the southern Arabah 1959-I990: summary of thirty years of archaeometallurgical field work in the Timna valley, the Wadi Amram and the southern Arabah (Israel)', Arx 2-3, 5-42.

al-Salameen, Z. et al., 2or . 'New Arabic-Christian inscriptions from Udhruh, southern Jordan', Arabian Archaeology and Epigraphy 22, 232-242.

Schick, R., 2007. 'Al-Humayma and the Abbasid family', Studies in the History and Archaeology of Jordan 9, 345-355.

Sharon, M., I993. 'Five Arabic inscriptions from Rehovoth and Sinai', IE7 43, 50-59.

Shatzmiller, M., I994. Labour in the Medieval Islamic World, Leiden: Brill.

Smith, A. M., 2005. 'Bir Madhkur project: a preliminary report on recent fieldwork', BASOR 340, 57-75.

Smith, A. M., and Niemi, T. M., I994. 'Results of the Southeast 'Arabah Archaeological Reconnaissance', $A D A 7$ 38, $469-483$.

Urman, D., I995. 'Excavations at Nessana I987-I995', Beer Sheva I7, I-90 (Hebrew).

Walmsley, A. G., I992. 'Fihl (Pella) and cities of north Jordan during the Umayyad and Abbasid periods', Studies in the History and Archaeology of Fordan 4, 377-385.

Walmsley, A. G., 200o. "Production, exchange and regional trade in the Islamic east Mediterranean: old structure, new systems?', in I. L. Hansen, and C. Wickham (eds.), The Long Eighth Century, Leiden: Brill, 265-343.

Watson, A. M., I983. Agricultural Innovation in the Early Islamic World, Cambridge: Cambridge University Press.

Whitcomb, D., I987. 'Excavation in Aqaba: first preliminary report', $A D A 7$ 31, 247-266.

Whitcomb, D., I988. 'Khirbet al-Mafjar reconsidered: the ceramic evidence', BASOR 27I, 5I-67.

Whitcomb, D., I989a. 'Mahesh Ware: evidence of early Abbasid occupation from southern Jordan', ADAJ 33, 269285 .

Whitcomb, D., I989b. 'Coptic glazed ceramics from the excavations at Aqaba, Jordan', JARCE 26, I67-182.

Whitcomb, D., I992. 'The Islamic period as seen from selected sites', in B. MacDonald (ed.), The Southern Ghors and Northeast 'Arabah Archaeological Survey, Sheffield: J. R. Collis, II3-i i8.

Whitcomb, D., I994. 'The Misr of Ayla: settlement at al-'Aqaba in the Early Islamic period', in G. R. D. King, and A. Cameron (eds.), The Byzantine and Early Islamic Near East II: Land Use and Settlement Patterns, Princeton: Darwin Press, I55-I70.

Whitcomb, D., I995. Ayla: Art and Industry in the Islamic Port of Aqaba, Chicago: Oriental Institute Museum Publications.

Whitcomb, D., 200I. 'Umayyad and Abbasid Periods', in B. MacDonald, R. Adams, and P. Bienkowski (eds.), The Archaeology of Fordan, Sheffield: Sheffield Academic Press, 503-513.

Whitcomb, D., 2006a. 'Land behind Aqaba: the Wadi Arabah during the Early Islamic period', in P. Bienkowski, and K. Galor (eds.), Crossing the Rift: Resources, Routes, Settlement Patterns and Interaction in the Wadi Arabah, Oxford: Oxbow Books, 239-242.

Whitcomb, D., 2006b. 'Archaeological evidence of sedentarization: Bilad al-Sham in the Early Islamic period', in S. R. Hauser (ed.), Die Sichtbarkeit von Nomaden und saisonaler Besiedlung in der Archäologie: Multidisziplinäre Annährerungen an ein methodisches Problem, Publikation des internationalen Kolloquiums in Halle (Saale), Dezember 2004, Halle: Orientwissenschaftliches Zentrum, 27-43.

Wilson, A. I., 2008. 'Hydraulic engineering and water supply', in J. P. Oleson (ed.), The Oxford Handbook of Engineering and Technology in the Classical World, Oxford: Oxford University Press, 285-318.

Yāqūt Ya'qūb b. 'Abd Allāh, ıgo6. Mu'jam al-Buldān, M. A. al-Khānj̄i (ed.), Miṣr, Cairo: muṭaba'at al-Sa'āda.

Yekutieli, Y., Shalev, S., and Shilstein, S., 2005. 'En Yahav—a copper smelting site in the 'Arava', BASOR 340, I-2I. 